Central Washington University

ScholarWorks@CWU

All Faculty Scholarship for the College of the Sciences

$9-2019$

\title{
Free and open source GIS in South America: political inroads and local advocacy
}

Sterling Quinn

Central Washington University

Follow this and additional works at: https://digitalcommons.cwu.edu/cotsfac

Part of the Geographic Information Sciences Commons

\section{Recommended Citation}

Quinn, S. (2019). Free and open source GIS in South America: political inroads and local advocacy. International Journal of Geographical Information Science, 34(3), 464-483. https://doi.org/10.1080/ 13658816.2019.1665672

This Article is brought to you for free and open access by the College of the Sciences at ScholarWorks@CWU. It has been accepted for inclusion in All Faculty Scholarship for the College of the Sciences by an authorized administrator of ScholarWorks@CWU. For more information, please contact scholarworks@cwu.edu. 
The following is the author's accepted edition of the article. The Version of Record of this manuscript was published in the International Journal of Geographical Information

Science in September 2019 and is available at

https://www.tandfonline.com/doi/full/10.1080/13658816.2019.1665672

Free and open source GIS in South America: political inroads and

\section{local advocacy}

Sterling Quinn

Department of Geography -- Central Washington University sterling.quinn@cwu.edu

Geographical information systems (GIS) practitioners worldwide enjoy a growing array of free and open source software (FOSS) options. This software has expanded the accessibility of GIS in economically developing countries while fostering local technical expertise. This article reviews FOSS GIS uptake and advocacy in South America, especially how it relates to a climate of political friendliness toward FOSS in the region. The use or absence of FOSS GIS is assessed in public-facing web maps in South America, first at the national government level, and then at the provincial level using Argentina as a country of study. Local technical support groups and software development initiatives surrounding FOSS GIS in South America are then summarized. Finally, three case studies are presented of notable efforts to build FOSS GIS technical communities at the local level: the FOSSGIS Brasil online magazine, the Geoinquietos Argentina professional network, and the FOSS.4GIS.GOV conference in Brazil. A study of the leaders, dynamics, and practices of these groups can inform others in similar circumstances around the world who are trying to promote FOSS GIS adoption, development, skills, and services.

\section{Introduction}

In the field of geographical information systems (GIS), free and open source software

(FOSS) offers a variety of choices rivaling commercial software alternatives (Steiniger 
and Hunter 2013). Here the term FOSS means software whose license is compliant with the Free Software Foundation's list of four essential freedoms: Freedom to run the program as you wish, freedom to study and change the program, freedom to redistribute copies, and freedom to distribute copies of your modified versions (Free Software Foundation 2018). Such software is alternatively known as free/libre open source software (FLOSS), or in Ibero-America, simply software libre/livre. In contrast, proprietary software restricts access to the source code and often requires license fees. Popular examples of FOSS GIS include QGIS, GRASS, gvSIG, and SAGA for desktopbased mapping and data processing, MapServer and GeoServer for web service publishing, Leaflet and OpenLayers for website programming, and PostreSQL with PostGIS for back-end data storage and query. Popular examples of proprietary GIS include ArcGIS, MapInfo, and Manifold GIS.

Most academic and professional activity surrounding FOSS GIS currently originates from North America and Europe ${ }^{1}$; however, it is important to pay attention to FOSS GIS in South America because (1) there is a substantial FOSS GIS adoption occurring in some South American governments, and (2) this uptake may be occurring for a different mix of reasons than observed or expected with FOSS adoptions in the Global North. Indeed, studying the use of FOSS GIS in South America reveals connections with the unique climate of FOSS acceptance across the continent and its frequent ties to leftist political ideas. Drivers of FOSS adoption in the region range from grass roots activism to top-down state-sponsored mandates. Regarding GIS, South

\footnotetext{
${ }^{1}$ One evidence of this is that the Open Source Geospatial Foundation (OSGeo), the principal non-profit organization seeking to advance FOSS GIS, rotates its annual conference on a three-year basis between North America, Europe, and the rest of the world.
} 
America has seen some unique local efforts to promote and support FOSS through media, conferences, and forward-looking technical communities whose operations deserve deeper study.

Understanding the adoption of FOSS GIS in South America requires the consideration of technical, economic, social, and political factors. This article first describes how South America as a region has been generally amicable toward FOSS and the reasons that current scholarship has given for this. Current trends in FOSS GIS use and development in South America are then summarized and situated within the region's political climate. The discussion concludes with three cases from Argentina and Brazil where people have been particularly successful with rallying the FOSS GIS community, and suggests how these practices might be applied effectively in other places.

\section{Public openness toward FOSS in South America}

South America has seen a unique variety of laws and decrees at the city, state, and federal levels promoting FOSS use on government computers. This includes at least five national level policies (Table 1), a rate higher than any other continent. By 2010, Lewis had tallied 57 FOSS-friendly policy actions (at any level of government) in the whole of Latin America. Puentes Vargas (2015) offers a more recent summary of the most significant ones in South America. These initiatives indirectly affect the private sector because government buying power can influence the software market, and the statesponsored universities that produce qualified engineers receive their research funds from the government (Câmara and Fonseca 2007). 
Beyond encouraging FOSS, some governments even mandate its use for state business. For example, Venezuela’s ‘Infogobierno’ law requires public institutions migrate to FOSS, and Bolivia has enacted a series of decrees leading toward public sector migration to FOSS. The 2010 survey by Lewis (p. 3) found that the tendency to adopt strict mandates of FOSS was more common in Latin America and Africa than in other parts of the world. Policies in other regions tended to take more of a hands-off advisory role.

\begin{tabular}{|l|l|l|l|}
\hline Country & FOSS-related policy & $\begin{array}{l}\text { Year } \\
\text { adopted }\end{array}$ & Summary \\
\hline Bolivia & $\begin{array}{l}\text { Decreto Supremo } \\
1793\end{array}$ & 2013 & $\begin{array}{l}\text { Requires the use of FOSS in government } \\
\text { computing. Follows Ley 164 from 2011 which } \\
\text { directed all levels of government to promote } \\
\text { and prioritize FOSS. Further directives for } \\
\text { migration were given in 2017 under Decreto } \\
\text { Supremo 3251. }\end{array}$ \\
\hline Brazil & $\begin{array}{l}\text { Instrução Normativa } \\
\text { no 04/2010/SLTI/MP }\end{array}$ & 2010 & $\begin{array}{l}\text { Requires the identification and consideration } \\
\text { of FOSS options as part of the government's } \\
\text { software acquisition process. }\end{array}$ \\
\hline Ecuador & Decreto 1014 & 2008 & $\begin{array}{l}\text { Establishes a policy that the national } \\
\text { government will use FOSS in public } \\
\text { administration, allowing only a few } \\
\text { exceptions, such as when no alternative } \\
\text { exists or when national security is at risk. }\end{array}$ \\
\hline Uruguay & Ley 19.179 & 2013 & $\begin{array}{l}\text { Gives preference to FOSS licensing during } \\
\text { the software acquisition process for a wide } \\
\text { range of state institutions. Use of other } \\
\text { software requires justification. Encourages } \\
\text { the use of FOSS in the educational system. }\end{array}$ \\
\hline Venezuela & Ley de Infogobierno & 2013 & $\begin{array}{l}\text { Mandates the use of FOSS in public } \\
\text { institutions and levies fines for } \\
\text { noncompliance. }\end{array}$ \\
\hline
\end{tabular}

Table 1: Notable country-level policies in South America related to government use of FOSS

Why have these South American governments been so aggressive about adopting FOSS? The following section explores the technical, economic, and social drivers behind the region's FOSS-friendly politics. This discussion provides important 
context for understanding the current momentum and advocacy for FOSS GIS in South America.

\section{Technical factors}

The use of information and communication technologies in Latin America and the Caribbean is increasing, but still varies widely from country to country and lags behind all other world regions except Sub-Saharan Africa (Baller et al. 2016). In the private sector, uptake is strongest among larger, skill-intensive, urban firms; but all sectors are hindered by a deficit of skilled workers (Grazzi and Jung 2019). In economically developing countries such as those in South America, digital piracy runs rampant, leading to complacency with proprietary software and actually facilitating vendor lockin (Yapa 1991; CENATIC 2010, p.74; Kamau and Namuye 2012). Recent government crackdowns on illegal software copying are leading public institutions to look for lowercost software alternatives (James 2003; Karume and Mbugua 2012). Some have turned to FOSS solutions, recognizing them as a way to not only economize, but also foster local skills, develop context-specific applications, and institute social changes (Câmara and Fonseca 2007).

In addition to specialized software like GIS, the FOSS adopted by governments includes operating systems, web servers, databases, and office software such as word processors and spreadsheet management programs. The nature of FOSS licenses allows anyone to audit and examine the source code of these programs, creating a line of defence against hacking and foreign sabotage (Oram 2011). These licenses also allow modification and redistribution of the code, providing a way to fix, enhance, or internationalize the software without waiting for a vendor to release a (potentially costly) upgrade (Shaikh and Cornford 2012). 
An attractive element of FOSS for the public sector is that the software can be distributed without licensing fees. The amount of money required to keep proprietary software running in government offices is substantial. For example, one Brazilian official estimated that between 1999 and 2004, the country paid \$1 billion in software licenses and royalties, and that it would take $\$ 2$ billion per year to begin paying for the pirated software its employees were using (Day to Day 2004). Perhaps more conservatively, the Brazilian federal data processing service SERPRO reported that Brazil saved over R $\$ 380$ million (roughly $\$ 160$ million USD) by adopting FOSS on public-sector computers during the early years of the Lula administration, 2003-2008 (SERPRO 2010).

Although the money saved on software licenses may be viewed as a decisive benefit of FOSS, the total cost of ownership (TCO) must also be considered. This includes migrating to the new software, training the staff who use it, and maintaining the system over time (Shaikh \& Cornford 2012). Ghosh (2003) argues that in economically developing countries, the advantages of FOSS are more pronounced because labor costs tend to constitute a smaller proportion of the TCO than they do in developed countries.

\section{Social factors}

The reasons for government promotion of FOSS in South America go beyond economics, and involve attitudes about society, sovereignty, and the role of the state. 
This is illustrated in a public debate between Microsoft Peru and legislator Edgar Villanueva over a proposed bill (later much watered-down) requiring the use of FOSS on Peruvian government computers. Microsoft warned that the mandate would lead to excessive migration costs, mismatches in platforms, and lowered productivity.

Villanueva and free software advocates countered that FOSS was the only way for the state to guarantee that citizens should be able to access public information, including the code that stored and protected their personal records (Chan 2004).

Chan (2004) noted that this line of reasoning represented a key difference from FOSS promotion in North America, where supporters tended to emphasize FOSS's protection of consumer freedoms. The South America-based FOSS advocates that helped craft Villanueva's response couched their argument in the protection of collective social rights. An Argentinean FOSS advocate involved in the debate remarked, 'Cost is important but it is only secondary. When we began to think about the possible insecurities in government systems that store [citizens'] personal data, and the way this data is handled, I as a citizen have an interest in how this is guarded' (quoted in Chan 2007).

\section{Political factors}

In South America, the idea of FOSS as an avenue to independence from the perceived imperialism of US-based proprietary software companies has appeared in the rhetoric of free software advocates all the way up to speeches made by heads of states. Zanotti 
(2014) quotes an Argentinean hacker' ${ }^{2}$ thus: 'If we talk about FOSS, we're going to wind up talking politics. We're not going to talk programming.' Connections between Peronist politics and FOSS are visible in blogs like Ubuntu Peronista and Si Evita viviera, sería Linuxera ${ }^{3}$, the latter of which contained a post celebrating that Evita 'can now have a socially just, economically free, and politically sovereign operating system' (quoted in Zanotti 2014). Along similar lines, the Uruguayan foreign minister Luis Almagro remarked that 'Free software is part of our agenda and our future because the values it represents are the same values of Uruguay: equality, freedom, sovereignty, right to choose, democracy, and development.' (UNESCO 2013)

Many of the strongest policies of FOSS support in South America came during the so-called 'pink tide' period of the early 2000s, wherein a surge of charismatic leftleaning leaders came to power on the promise of challenging neoliberal hegemonies in the region. As part of this agenda, they eagerly promoted free software as an alternative to US-made proprietary software. In April 2007, then-president of Ecuador Rafael Correa went so far as to go on television and declare that the public adoption of FOSS was 'an important step for the integration and, why not say it, the liberation of Latin America.' ${ }^{4}$ All of Bolivia's FOSS-related policies have come into being under Evo Morales, in order to 'break the bands of technological and informational dependence' and guarantee technological sovereignty, according to the text of the decrees. ${ }^{5}$ In

\footnotetext{
${ }^{2}$ In the FOSS developer community, the term 'hacker' is often used as a term of respect for someone with high technical skill, and is not necessarily associated with nefarious activity.

3 'If Evita were still alive, she'd be a Linux user'

${ }^{4}$ Todos a utilizar software libre. Let's use Free Software. Published on YouTube on 25 April 2007 by presidenciaecuador. https://www.youtube.com/watch?v=59PyU_7iqaU

${ }^{5}$ Decreto Supremo 1793, Article 4, Section IV
} 
Venezuela, Hugo Chávez repeatedly linked FOSS to socialist doctrine and promoted it using terms like 'freedom', 'equality', and 'independence'. The politicizing of FOSS in this way sometimes made software migration a tough sell to those who did not agree with Chávez' revolution, but from a policy perspective it led to one of the strictest FOSS mandates in the region (Maldonado 2010, Puentes Vargas 2015).

FOSS was also promoted aggressively by Brazil's president Luiz Inácio Lula da Silva's administration in the early 2000s. In Brazil, many political parties emphasize openness as a value of the state (Shaikh \& Cornford 2012), and Lula's administration appointed FOSS advocates to high-level posts in the government's Institute for Information Technology (Birkinbine 2016, Milano 2016). Many of these individuals had come of age during Brazil's military dictatorship and had been active in labor unions and opposition movements in addition to their software activities (Shaw 2011, Evangelista 2014). They got their start promoting FOSS in universities and lower levels of government, particularly in the state of Rio Grande do Sul. They were also instrumental in launching the Fórum Internacional Software Livre (International Free Software Forum, or FISL), which today is one of the largest regular gatherings of the Latin American FOSS community.

The influence of these 'insurgent experts', as Shaw (2011) calls them, led Lula's government to form the Technical Committee for the Implementation of Free Software (CISL). Roughly a dozen federal agencies migrated to FOSS during this period, although the effort was hindered by opposition from proprietary software companies and bureaucrats who wanted to keep their current software. Both often complicate the implementation of FOSS mandates, as do constraints on training and migration budgets.

In 2010, Brazil passed Instrução Normativa MP/SLTI No 4 stating that 
government entities should consider FOSS options when conducting feasibility analyses for software purchases (Birkinbine 2016). This was a win for the FOSS advocates; nevertheless, Microsoft regained momentum during the Rousseff and Temer administrations and maintains substantial presence in the Brazilian government software $\operatorname{mix}($ Dias 2016).

Through the policy battles, the FOSS community sometimes struggles to maintain a unified purpose and approach. Evangelista (2014) sees a schism between what he and free software pioneer Richard Stallman (2016) have termed the 'free' and the 'open' camps. A young group of technical professionals and 'nerds' interested in business careers are focusing on the production of high quality FOSS software products, regardless of which for-profit organizations might help create or adopt them. They believe that this willingness to see beyond ideological lines will contribute most to the advancement and expansion of the FOSS community. This 'open' camp is much less interested in the purism and political propaganda of their rival 'free' camp, which is wary of corporate involvement in FOSS development and consists mainly of bureaucrats and activists. The relationship between the two groups is complicated and the more politicized 'free' camp still wields significant power in community gatherings in Brazil. Such complexities may be present in other FOSS communities throughout South America.

\section{FOSS GIS in South America}

Some of the earliest discussions about GIS and society raised warnings about the cost of the software and its effect on accessibility (Sheppard 1995, Harris and Weiner 1996). Prior to the development of most FOSS GIS software, Yapa (1991) remarked that the 
high price tag of commercial GIS rendered it out of reach for students, teachers, and small shops in developing countries. He suggested that the development of 'public domain GIS' could help remedy this. Around that time period, a few FOSS GIS projects such as GRASS and MapServer were gaining momentum. Now, numerous FOSS options allow for desktop-based GIS data processing, cartography, web service hosting, and web application development (Steiniger and Hunter 2013). This software operates using open data specifications developed by both proprietary firms and communitybased consortia. ${ }^{6}$ The use of FOSS is part of a broader shift toward an open culture for GIS that includes open data, open research, and open education (Sui 2014).

How does one determine the strength of the FOSS GIS community and landscape in any particular geography, including South America? Studies such as that of Gonzales-Barahona et al. (2008) focus on detecting the locations of FOSS developers or elaborating on the dynamics of the developer community; yet, we know comparatively little about the adopters of FOSS and how they have fared (Aksulu and Wade 2010). Ways to assess regional strength and momentum of FOSS GIS could include evaluating cases of software implementation, documenting the presence and activity of local technical communities, and investigating any software developed to meet local needs. The following sections discuss each of these aspects in a South American context.

${ }^{6}$ KML (Keyhole Markup Language) and the Esri shapefile are examples of open spatial data formats originally developed by proprietary firms. In contrast, formats such as the Web Map Service (WMS) were developed by the Open Geospatial Consortium (OGC). 
Glimpsing implementation patterns through a study of publicly-available web

maps

Just as with general FOSS, there are evidences of strong currents of FOSS GIS uptake

and advocacy throughout South America, although some of these are localized in nature and more detailed studies need to be carried out in individual countries or subregions.

For example, surveying public or private organizations to ask about GIS software preferences would be a useful approach. One can also discern quite a bit about software usage trends by looking at tools used in publicly available GIS and mapping websites. To demonstrate that a variety of South American government GIS groups actively use FOSS, the latter method is applied here at two scales of geography.

Most South American countries have a mapping agency that shares online geographic data and web services with the public. These agencies often host interactive web maps wherein users can explore the available geographical layers or obtain general information about the country. Table 2 below shows the addresses of the principal map visualization websites for 10 countries, the technology used to build each, and whether or not this technology could be considered FOSS. In this table, the 'principal viewer' is considered to be the one coming from the agency responsible for the country's geography, mapping, or spatial data infrastructure activities. The technology was discerned by looking at the web site source code files and network traffic, which is information obtainable for any website whether it is built with FOSS or not. 


\begin{tabular}{|c|c|c|c|c|}
\hline & $\begin{array}{l}\text { Principal government map } \\
\text { viewer }\end{array}$ & URL (accessed September 2018) & Technologies used & FOSS \\
\hline Argentina & IGN Visualizador de Mapas & $\begin{array}{l}\text { https://ide.ign.gob.ar/portal/apps/webappvie } \\
\text { wer/index.html }\end{array}$ & $\begin{array}{l}\text { Esri ArcGIS } \\
\text { Enterprise, ArcGIS } \\
\text { API for JavaScript }\end{array}$ & No \\
\hline Bolivia & GeoBolivia geovisualizador & https://geo.gob.bo/mapfishapp/ & GeoServer, MapFish & Yes \\
\hline Brazil & SIG IBGE & http://mapasinterativos.ibge.gov.br/sigibge/ & $\begin{array}{l}\text { Esri ArcGIS } \\
\text { Enterprise, ArcGIS } \\
\text { API for JavaScript }\end{array}$ & No \\
\hline Chile & $\begin{array}{l}\text { Geoportal de Chile - Visor de } \\
\text { Mapas }\end{array}$ & http://www.geoportal.cl/visorgeoportal/ & $\begin{array}{l}\text { Esri ArcGIS } \\
\text { Enterprise, ArcGIS } \\
\text { API for JavaScript }\end{array}$ & No \\
\hline Colombia & $\begin{array}{l}\text { IGAC Geoportal (various } \\
\text { apps) }\end{array}$ & http://geoportal.igac.gov.co/ & $\begin{array}{l}\text { Esri ArcGIS } \\
\text { Enterprise, ArcGIS } \\
\text { API for JavaScript }\end{array}$ & No \\
\hline Ecuador & $\begin{array}{l}\text { Geoportal IGM Visor de } \\
\text { Datos Geográficos Oficiales }\end{array}$ & $\begin{array}{l}\text { http://www.geoportaligm.gob.ec/portal/inde } \\
\text { x.php/visualizador/ }\end{array}$ & $\begin{array}{l}\text { GeoServer, Terria } \\
\text { Map }\end{array}$ & Yes \\
\hline Guyana & (Could not identify a viewer) & & & \\
\hline Paraguay & Portal Paraguay - Mapas & https://mapas.paraguay.gov.py/ & Google Maps API & No \\
\hline Peru & $\begin{array}{l}\text { GeoIDEP Visor de Mapas del } \\
\text { Perú }\end{array}$ & http://mapas.geoidep.gob.pe/mapasperu/ & $\begin{array}{l}\text { Esri ArcGIS } \\
\text { Enterprise, ArcGIS } \\
\text { API for JavaScript }\end{array}$ & No \\
\hline Suriname & (Could not identify a viewer) & & & \\
\hline Uruguay & IDE UY Visualizador & http://ide.uy/visor/ & $\begin{array}{l}\text { GeoServer, } \\
\text { OpenLayers }\end{array}$ & Yes \\
\hline Venezuela & $\begin{array}{l}\text { Geoportal Nacional Simón } \\
\text { Bolívar }\end{array}$ & $\begin{array}{l}\text { http://visor.ide.igvsb.gob.ve/nacional/portal. } \\
\text { php }\end{array}$ & $\begin{array}{l}\text { GeoServer, } \\
\text { OpenLayers }\end{array}$ & Yes \\
\hline
\end{tabular}

Table 2: Technologies used by national governments in South America to produce web maps for geographic data exploration

Notably, the four countries using FOSS GIS for their principal map viewers (Bolivia, Ecuador, Uruguay, and Venezuela) are the same ones that have supported FOSS through legislation or decree at the national level. Brazil is the only country with national support for FOSS that is not using FOSS in its principal map viewer, yet Brazil's support of FOSS is not as binding as some of the other countries' policies. Despite these countries' ongoing challenges with fully implementing general FOSS migration policies (Machado 2017), it appears that the policies are affecting GIS and mapping services. As an example, Molina Rodriguez and Lesage (2013) describe how Bolivia designed its spatial data infrastructure to support a FOSS-based web viewer. 
The situation is more complex than can be conveyed in the above chart because some lower level ministries, or even different offices of the same ministry, may conduct mapping activities and maintain online map viewers using different mixes of software. For example, although Argentina's National Geographical Institute (IGN) is not using FOSS in its main public-facing map viewer, its employees use FOSS GIS from day to day as described later in this paper, and the institute hosted a major conference in the use of FOSS GIS in 2017.

Software trends in provincial and municipal governments can differ markedly from software used at the national level. For example, using the same methods it can be seen that nearly all of Argentina's provincial governments are using FOSS in their map viewers. Table 3 shows that among the 23 Argentinian provinces and the federal district, 16 offer a map viewer built with FOSS GIS, while one has built a map viewer using proprietary GIS software. These numbers contrast with the strong market presence held by proprietary GIS software in state governments in the United States. ${ }^{7}$

${ }^{7}$ For example, see https://orthos.dhses.ny.gov/ in New York State and http://gisweb.glo.texas.gov/glomapjs/index.html in Texas, both built with Esri software. An example of a state running a FOSS GIS web map is Oklahoma at https://okmaps.org/OGI/search.aspx, but this is a rare exception in the US. 


\begin{tabular}{|c|c|c|c|}
\hline & URL (accessed November 2018) & Technologies used & FOSS \\
\hline Buenos Aires & Viewer not found or not functional & & \\
\hline Capital Federal & $\begin{array}{l}\text { https://idecaba.estadisticaciudad.gob.ar/maps/ne } \\
\text { w }\end{array}$ & GeoServer, GeoExplorer & Yes \\
\hline Catamarca & http://200.43.169.149/ & GeoServer, GeoNode & Yes \\
\hline Chaco & http://idechaco.gob.ar/sigide/ & GeoServer, GeoExt & Yes \\
\hline Chubut & http://ide.estadistica.chubut.gov.ar/mapas/ & GeoServer, OpenLayers & Yes \\
\hline Córdoba & https://idecor-ws.cba.gov.ar/maps/5/view & GeoServer, GeoExplorer & Yes \\
\hline Corrientes & $\begin{array}{l}\text { https://www.arcgis.com/apps/Publiclnformation/i } \\
\text { ndex.html?appid=754d728c2ffc46d1b5bb5d300b } \\
152150\end{array}$ & Esri ArcGIS Online & No \\
\hline Entre Ríos & Viewer not found or not functional & & \\
\hline Formosa & http://idef.formosa.gob.ar/visor/ & GeoServer, GeoExt & Yes \\
\hline Jujuy & $\begin{array}{l}\text { http://190.52.39.247:9880/mapas/application/vis } \\
\text { or_de_mapas_idej }\end{array}$ & GeoServer, MapBender & Yes \\
\hline La Pampa & Viewer not found or not functional & & \\
\hline La Rioja & https://visor2.iderioja.larioja.org/mapa.php & MapServer, OpenLayers & Yes \\
\hline Mendoza & http://idemza2.mendoza.gov.ar/ & GeoServer, Heron MC & Yes \\
\hline Misiones & $\begin{array}{l}\text { http://www.ide.misiones.gov.ar/index.php?optio } \\
\text { n=com_content\&view=article\&id=8\&ltemid=3 }\end{array}$ & MapServer, OpenLayers & Yes \\
\hline Neuquén & $\begin{array}{l}\text { http://ideneu.neuquen.gov.ar:8080/geo/compose } \\
\text { r/ }\end{array}$ & GeoServer, GeoExplorer & Yes \\
\hline Río Negro & http://ide.extranet.rionegro.gov.ar/maps/new & GeoServer, GeoExplorer & Yes \\
\hline Salta & http://geoportal.idesa.gob.ar/maps/455/view & GeoServer, GeoExplorer & Yes \\
\hline San Juan & Viewer not found or not functional & & \\
\hline San Luis & Viewer not found or not functional & & \\
\hline Santa Cruz & Viewer not found or not functional & & \\
\hline Santa Fe & https://www.santafe.gov.ar/idesf/visualizador/ & MapServer, GeoExt & Yes \\
\hline $\begin{array}{l}\text { Santiago del } \\
\text { Estero }\end{array}$ & https://www.santafe.gov.ar/idesf/visualizador/ & OpenLayers (server unknown) & Yes \\
\hline Tierra del Fuego & Viewer not found or not functional & & \\
\hline Tucumán & http://idet.tucuman.gob.ar/visor/ & GeoServer, GeoExt & Yes \\
\hline
\end{tabular}


Table 3: Technologies used by Argentinian provincial governments to produce public web maps for geographic data exploration

Most of the provincial sites in the above table are using well-known and basic FOSS GIS software such as OpenLayers, MapServer, and GeoServer. Stability and long-term maintenance of some of the sites appear to be challenges: occasionally the streaming map layers were not operational when accessed for this study, even when the rest of the site appeared to be functional. ${ }^{8}$ More research is required to understand whether these challenges are due to underfunding, difficulties with finding or retaining skilled workers, the dynamics between governments and consultants, deficiencies in the software itself, or other reasons.

\section{Local technical support groups for FOSS GIS}

Another evidence of FOSS GIS activity is the presence of local technical support networks where software users can exchange troubleshooting tips, share ideas and success stories, post employment information, and arrange conferences and meetups of people with similar skills and interests. As has been observed with FOSS in general, these 'communities' offer access to technical help, friendships, and recognition; and are held together with shared philosophical motives (Zanotti 2012). They foster local expertise, and facilitate expanded software choices by promoting documentation, training, and translation of software (Câmara and Fonseca 2007).

OSGeo, a global nonprofit organization dedicated to the promotion of open geospatial technology, has fostered a number of these communities (Brovelli et al.

\footnotetext{
${ }^{8}$ Sites that were entirely unusable do not have a web address listed in Table 3.
} 
2012). ${ }^{9}$ OSGeo offers local chapters that fill the need for language-specific support in places like Korea, Italy, and Japan (OSGeo 2017). These chapters provide resources such as translated documentation, regional user meetups, a mailing list, and social media feeds. In Ibero-America, the Spanish language chapter of OSGeo has been supplemented by more localized chapters of a group called Geoinquietos, with chapters appearing in Argentina, Bolivia (Santa Cruz), and Brazil (Brasília). The case of Geoinquietos Argentina is examined in more detail later in this paper. A similar global network of support groups called Maptime, more geared toward beginners, has also seen chapters created in Bogotá, Colombia and Campinas, Brazil, but these appear to have waned while Geoinquietos and other organized efforts have increased in popularity. ${ }^{10}$

A few other regional gatherings have established some momentum, including the FOSS.4GIS.GOV conference series focused on government applications in Brazil (also mentioned below). Regional 'State of the Map' conferences discussing the crowdsourced geographic database OpenStreetMap and related tools have been held in São Paulo and Lima, and a worldwide State of the Map came to Buenos Aires in 2014. Members of Geoinquietos Argentina were instrumental in hosting that conference.

Some user groups are organized around a certain product or project. Technical support groups for the popular desktop GIS program QGIS have been registered in Brazil, Perú, and Colombia. They hold meetups, offer workshops, broadcast news on

\footnotetext{
${ }^{9} \mathrm{https}$ ://www.osgeo.org/about/

${ }^{10}$ Maptime is a worldwide network of local meetup groups that teach digital mapping skills with an emphasis on beginner-friendliness and the use of FOSS. These groups communicate almost entirely through Twitter, blogs, and signup sites like Meetup.com.
} 
social media, and provide links to technical resources including consultants who specialize in FOSS GIS. QGIS Brasil contributed to the software development by translating the interface into Portuguese, thereby enabling uptake of the software by a wider user base (Nanni 2016).

Other groups are organized around particular causes or identities. These include the various YouthMappers chapters operating out of at least four universities in Colombia, part of a global network of student-based groups that employ open geospatial technologies toward service and humanitarian mapping efforts. ${ }^{11}$ Another example is GeoChicas, which has rallied women to increase the breadth of features included in OpenStreetMap and highlight gender inequalities inscribed on the cultural landscape, such as the relatively small percentage of streets named after women (Revista de la Universidad 2018). ${ }^{12}$ The group started in Ibero-America and has spread into the United States, Africa, and many parts of Europe. Its FOSS-based re-mappings of gendered spaces are a noteworthy contribution to critical and feminist GIS praxis (Pavlovskaya and St. Martin 2007). ${ }^{13}$

\section{Local software development}

An important indication of FOSS GIS presence in any region is the local production and improvement of software. Indeed a common argument for government support of FOSS

\footnotetext{
${ }^{11} \mathrm{http}: / /$ www.youthmappers.org

${ }^{12} \mathrm{http}: / / w w w . g e o c h i c a s . o r g$

${ }^{13}$ https://wiki.openstreetmap.org/wiki/GeoChicas
} 
is that money should be invested toward local technical expertise and programming, rather than giving the money to foreign corporations (Maldonado 2010; Evangelista 2014; Milano 2016). FOSS development is evidence of this process occurring. FOSS GIS development efforts in South America include the aforementioned translation of user interfaces, the testing and use of products, and the creation of new software to meet community needs.

Ibero-America has incubated several FOSS GIS programs that are widely used in South America. One of these is gvSIG, a desktop GIS program developed in Valencia, Spain. It is attractive to South American institutions because its interface is originally developed in Spanish, and much of the documentation and support for the product is available in Spanish and Portuguese. This allows new users to get their bearings in GIS without the burden of a language barrier. Out of the gvSIG's 15 worldwide user groups, eight are based in South American countries ${ }^{14}$ and several have held regional conferences promoting the software.

Another GIS, called SPRING, was developed by the Brazilian National Institute for Space Research (INPE) (Câmara et al. 1996). SPRING's emphasis is in processing and extracting information from remotely sensed data, although it also supports vector data. The software was always free, and after a code cleanup it was eventually released under an open source license. At over 1 million lines of code, it remains in common use in Brazilian universities and government applications (Medeiros 2011).

Other open source GIS tools developed by Brazilian government and educational institutions include i3Geo, E-foto, and TerraLib. i3Geo is a web mapping

\footnotetext{
${ }^{14} \mathrm{http}: / / \mathrm{www} . g v s i g . c o m / p t / c o m u n i d a d e / g r u p o s-d e-c o m u n i d a d e s$
} 
and geoprocessing framework originally developed by the Brazilian ministry of the environment and currently maintained by the ministry of health. ${ }^{15}$ E-Foto is photogrammetry workstation software developed at the State University of Rio de Janeiro (UERJ). Its goal is to provide a cost-accessible way for students to learn about digital photogrammetry workflows (Mota et al. 2012). Finally, TerraLib is a software library supporting spatio-temporal modeling, data mining, and analysis, particularly for social and environmental applications. It was developed by INPE with support from Catholic University of Rio de Janeiro (PUC-RIO) and FUNCATE, a non-profit organization that develops GIS applications. According to Câmara and Fonseca (2007), TerraLib's purpose was to offer Brazilian users an alternative to commercial GIS software so that they could avoid vendor lock-in. A complementing product is TerraView, a general-purpose GIS that can work with TerraLib databases (Câmara et al. 2008).

\section{Case studies of FOSS GIS community activity}

Cases of regional success in disseminating information, building technical support communities, and training individuals may offer helpful lessons for those interested in cultivating more FOSS GIS activity. This is especially true in countries that are under mandate to use or give preference to FOSS. The remainder of this paper discusses three notable efforts from Argentina and Brazil.

\footnotetext{
${ }^{15} \mathrm{https}: / /$ softwarepublico.gov.br/social/i3geo
} 


\section{FOSSGIS Brasil magazine}

Perhaps the most ambitious effort ever to publish information about FOSS GIS in periodical format was a Portuguese language magazine launched by the Brazilian systems analyst Fernando Quadro in 2011. Quadro noticed that there was a lot of interesting work occurring in FOSS GIS in Brazil, but the reporting on it was scattered throughout different publications, some of them centered on proprietary software.

Quadro sent out invitations to people whose work he admired, and asked them if they wanted to help create a publication entirely about FOSS GIS (Mendonça 2012). The result was a digital magazine called FOSSGIS Brasil that saw six colorful and information-packed issues in 2011-2012 with the goal of releasing on a quarterly cycle. Issue length ranged from about 50 to 80 pages.

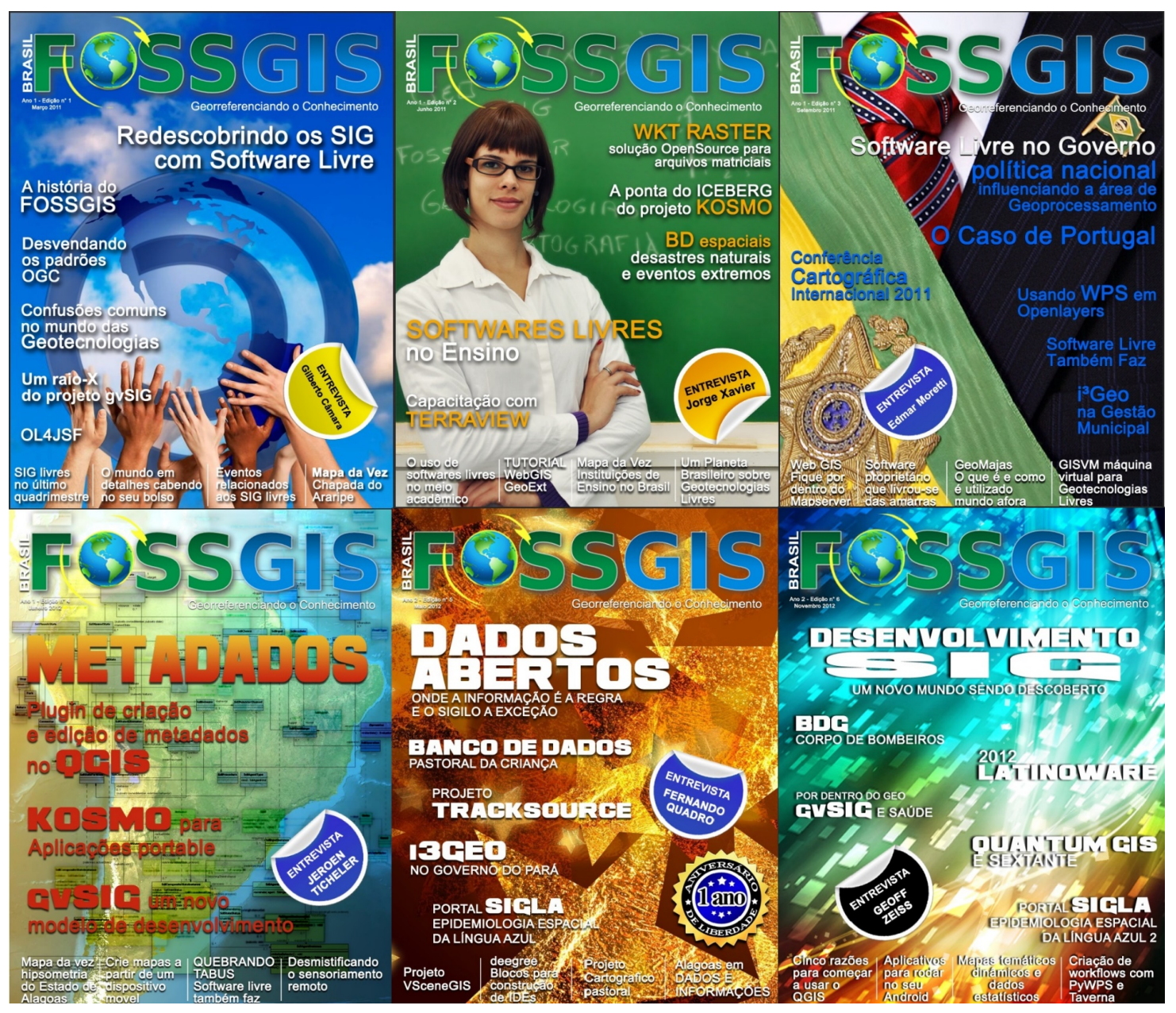


Figure 1. Issues of FOSSGIS Brasil published in $2011-2012$.

Members of the initial editorial core reached into their professional networks to find FOSS GIS experts who could write content. The magazine included articles about FOSS GIS software options, a column comparing functionalities of FOSS GIS with proprietary software, case studies of successful software implementations in various branches of the Brazilian government, and interviews with figureheads in the Brazilian FOSS GIS community. For example, one issue included a conversation with Gilberto Câmara, then president of INPE, about the development of the SPRING GIS (Medeiros 2011). A map gallery section in the magazine allowed GIS analysts and cartographers working in Brazilian industries and governments to showcase their work. Contributors to the gallery included geographers, teachers, and government planning officials at the state and municipal levels.

The professional scope and appearance of the magazine belied the fact that it was produced entirely by volunteers, many of whom were also raising families, working full time jobs, or even running their own businesses. With these many commitments faced by the contributors, the original goal of a quarterly publication became difficult to sustain. FOSSGIS Brasil reached an abrupt end after approximately a year and a half, but its longer-term benefits included the friendships and professional relationships forged by the volunteer contributors, some of whom lived thousands of kilometers apart and could only communicate through e-mail (F. Quadro, personal communication, 15 October 2018). Additionally, the back issues of the magazine are still available online and constitute a useful Portuguese-language primer on available FOSS GIS options at the time (much of which is still applicable). 
The FOSSGIS Brasil identity continues today as a Facebook and Twitter feed, and Quadro maintains an active technical blog. ${ }^{16}$ These social media channels allow for a more frequent publishing cycle, and they are easier to maintain than a full length magazine.

\section{Geoinquietos Argentina}

Geoinquietos is a network of local groups throughout Ibero-America interested in geospatial sciences and FOSS. The Geoinquietos Argentina chapter has been one of the most active of these groups, repeatedly organizing conferences that attract hundreds of people from the Southern Cone area of South America and beyond. The history of Geoinquietos Argentina can be traced to the founding of the Spanish language chapter of OSGeo in 2007. As Spanish is spoken across a broad geographic region, there was a need for more local interest groups where people could connect face to face and share information relevant to a particular city or country. Thus, a list of 'Geoinquietos' chapters eventually took shape on the OSGeo Spanish wiki page. ${ }^{17}$ The Spanish word inquieto means restless or edgy; describing this group's affinity toward constant activity and self-improvement.

The first few Geoinquietos chapters were in Spain, but in May 2012, Mauricio Miranda added a link to the Geoinquietos Buenos Aires chapter (now Geoinquietos Argentina), the first one in the Western Hemisphere. Since that time, other Geoinquietos

\footnotetext{
${ }^{16} \mathrm{http}: / /$ www.fernandoquadro.com.br/html/

${ }^{17}$ https://wiki.osgeo.org/wiki/Cap\%C3\%ADtulo_Local_de_la_comunidad_hispanohablante
} 
chapters have appeared throughout the region. The fact that Brazil and Portugal have also seen the formation of chapters suggests that the Geoinquietos brand and mission may be more strongly associated with Ibero-American identity rather than the Spanish language.

Geoinquietos Argentina organized 'FOSS4G Argentina' conferences in 2013, 2016, 2017, and 2019 (which occurred after the initial submission of this manuscript). These were a local variation of OSGeo's flagship FOSS4G conference for all things related to FOSS GIS. The 2017 conference went under the dual moniker FOSS4G+SOTM to indicate its affiliation with the State of the Map OpenStreetMap conferences. It was held over a six-day period that October at the Argentinian National Geographical Institute (IGN) in Buenos Aires. The event included a round table meetup day for educators, two days of technical workshops, two days of technical presentations with up to three concurrent session tracks, and a hackathon day wherein participants contributed to FOSS GIS projects such as OpenStreetMap, GeoNetwork, and pgRouting.

During one of the plenary sessions of the FOSS4G Argentina 2017, Miranda acted as a spokesperson for Geoinquietos Argentina to present an overview of the group and its practices (Miranda 2017). ${ }^{18}$ The purposes he listed for the group include a mix of seriousness and leisure: to learn, to have fun, to work, to earn money, to teach, to eat asado (traditional Argentinian barbecue), to drink beer, and to change the world.

\footnotetext{
${ }^{18}$ The information from this session comes from the author's notes taken while in attendance. The author is not aware of any transcripts or videos from this conference; however, the people mentioned in this subsection have read and approved the author's representation of their words.
} 
Miranda describes the group as completely anarchic; there is no hierarchy of participants. He is candid that increasing members' earning power and business potential with FOSS is a real objective ('we're not hippies'), a characteristic of Evangelista's (2014) ‘open' camp mentioned earlier; however, the group's philosophy differs from that of commercial software developers: the main objective is to share knowledge and effort. Although Miranda concedes that this may seem underwhelming, he points out that government entities such as provinces often pay private GIS consulting companies for the same services over and over, and that such redundancy is wasteful when communities could share technical information.

Geoinquietos accomplishes its mission through meetings, informal social gatherings ('geobeers'), workshops, FOSS4G conferences, a mailing list, an online mobile messaging group, and a Twitter account. The group has received support from Argentina's geographical institute IGN, evidenced through the conference venue, but also through the FOSS advocacy of some of its employees, including its (then) Director of Spatial Information Horacio Castellaro. Speaking on an impromptu panel during this same session, Castellaro mentioned his desire for the institute to become entirely free from ties to commercial software. He emphasized that every peso spent on commercial software is a peso lost from the country, and Argentina does not have a way to get that peso back. In his view, pesos spent on FOSS will help a broader group of stakeholders.

Also on this panel, conference director Malena Libman shared how Geoinquietos lent her the social and technical support needed to finish her degree in geospatial technologies. The growth of Geoinquietos is important, she said, because the world consists of more than Europe and the United States. The expansion of FOSS in Argentina has allowed new data to be published that previously was unavailable.

Although the Geoinquietos organizers worked long hours to hold the conference and the 
admission charge was under \$17 USD, Libman only asked that participants 'pay' them with their participation in the community.

Conference organizers announced that over 115 people attended the event, representing various forms of government, private industry, and universities. Perhaps the scarcity of similar conferences in neighboring countries fueled the diverse attendance, which included participants from Chile, Brazil, Paraguay, and Venezuela. Additional countries represented by speakers on the agenda included Spain, Mexico, Peru, Italy, and the United States.

How has Geoinquietos Argentina been so successful at organizing large, technical, low-cost, and attractive conferences on such a regular basis, bringing together members throughout a geographically large and diverse country? As evidenced by the panel session previously referenced, the group has benefitted from a core of highly dedicated and consistent individuals, rather than one person doing the majority of the work. It has also found strength by allying with groups that have similar interests, but slightly different social and technical avenues of focus. For example, in 2019 Geoinquietos Argentina joined forces with OpenStreetMap Argentina and GeoChicas to officially register as a non-governmental organization under the laws of Argentina. This organization calls itself GeoLibres, or "the geo-free". ${ }^{19}$ Its formation was meant to be a signal of long-term commitment toward the technical communities served by these groups (M. Miranda, personal communication, 3 December 2018).

Many of the group's members are young professionals who have come to know each other well through local events and the group's communication channels. These

\footnotetext{
${ }^{19} \mathrm{http}: / /$ geolibres.org.ar/
} 
bonds have been strengthened by the group's use of the Telegram messaging system as a primary means of communication. Telegram can be thought of as a kind of public chat room that happens in a mobile app. The use of Telegram distinguishes Geoinquietos Argentina from many other FOSS GIS special interest groups that use traditional mailing list technology, hearkening back to a generation that used e-mail more than text messages. Even social media feeds such as Twitter are perhaps too formal and organized to facilitate the style of jovial, relaxed, and occasionally very technical banter that characterizes the Geoinquietos Argentina Telegram chat.

The group has also focused on inclusivity, recently changing some of its branding and communication to use the more gender-neutral term Geoinquiet@s. The holding of the conference at a government facility likely lowered costs, helping the group to welcome persons from a variety of industries, countries, and skill levels. The inclusion of technical workshops, educator forums, and hackathons expanded the tent of participants and added value to the conference experience, giving conference-goers multiple reasons to justify their attendance and get the most return on travel investment.

Geography itself may also play a role in the group's success, as Argentina's economy and government are dominated by Buenos Aires, a city of nearly 15 million people that is well connected to other regions of the country (United Nations 2018, p. 25). For many attendees, participation involves hopping onto a car, bus, or subway, or at most a single short airplane flight. Events throughout the year bring participants together often, such that the FOSS4G conferences are not the only times they gather. Other South American primate cities such as Lima, Santiago, and Montevideo might offer significant bases of potential interest that could incubate local technical communities. In larger countries or those without a primate city, such as Brazil, circumstances are different. Brazil's geography with several major technical and 
economic centers apart from the capital might make it challenging to form a core group of organizers, although it could certainly create the circumstances for many

knowledgeable and enthusiastic participants.

\section{FOSS.4GIS.GOV conferences in Brazil}

The success of Geoinquietos Argentina at gathering the FOSS GIS community was noticed in other areas of South America. Fernando Quadro, the once-editor of the FOSSGIS Brasil magazine series, lamented on his blog: ‘How come we haven’t been able to hold an event of this [FOSS4G Argentina] size here in Brazil? . . . I wonder why a country as big as Brazil, with so many competent people engaged with open source GIS doesn't have an annual event to get the community together, share experiences, network, and socialize' (Quadro 2016). Following Quadro's post it appears some movement was made toward organizing a FOSS4G Brazil conference in 2017, but plans were ultimately scrapped.

Actually, several notable gatherings of open source GIS software enthusiasts have occurred in Brazil's capital, but they have largely focused on government applications. In both 2016 and 2018, the FOSS.4GIS.GOV conference brought together hundreds of professionals from various arms of government to share their experiences with free and open source geospatial technology. Speakers at these conferences have included representatives from the country's data processing service SERPRO, the Brazilian Institute of the Environment and Renewable Natural Resources (IBAMA), the Chico Mendes Institute for Biodiversity Conservation (ICMBio), the National Telecommunications Agency (ANATEL), the Federal Police, and the Army. State level government employees, university professors, and volunteers from QGIS Brasil have 
also given presentations. Attendance at the events was free, and the proceedings were posted on YouTube, constituting a useful Portuguese-language source of information for the geospatial FOSS community. ${ }^{20}$

Both iterations of FOSS.4GIS.GOV were hosted at IBAMA headquarters in Brasília, and admission was free. At the opening ceremony of the 2018 conference, IBAMA's vice-president Luciano Evaristo stated that all the anti-deforestation missions that the organization carries out in conjunction with federal and local police begin with geoprocessing tools. Evaristo noted that he saw long ago the economic value of replacing proprietary GIS software licenses with open source ones, but he was also impressed by the software quality that IBAMA gained by implementing FOSS. ${ }^{21}$

Instrumental in IBAMA's migration to open source GIS software was George Porto Ferreira, general coordinator of its National Center for Environmental Information and Monitoring (CENIMA). His team is active in the Amazon deforestation detection work mentioned by Evaristo. Working with longtime FOSS GIS community member Luiz Pacheco Motta and other colleagues from IBAMA, Ferreira spearheaded the FOSS.4GIS.GOV conference series. The first gathering in 2016 received some funding from European Union sources and welcomed visiting representatives from Denmark and Italy. The 2018 conference did not receive this funding, but saw the conference move closer toward association with the mainline FOSS4G conference series. ${ }^{22}$ OSGeo

${ }^{20}$ At the time of this writing, the 2016 and 2018 proceedings are available in playlists at https://www.youtube.com/user/gorgjo/playlists

${ }^{21}$ Evaristo's talk from the opening ceremony is available at https://www.youtube.com/watch?v=n1bCDCbovHA.

${ }^{22}$ Evidences of this include the FOSS4G signature 'ribbon' emblem in the conference logo and the presence of keynote speaker Jeff McKenna from the OSGeo board of directors. 
appears to be a potential future source of funding that could help ensure the longevity of the event, although a bigger factor may be the continued ability and initiative of IBAMA and its employees (or a comparable agency) to support the conference on a regular basis.

\section{Conclusions}

FOSS GIS has a strong and growing presence in South America, evidenced by government use of FOSS in interactive map websites, the variety of FOSS technical support groups for GIS and mapping, and the development of software to meet local geoprocessing needs. Some of this success is likely due to the generally friendly attitude toward FOSS throughout the region, where some governments have mandated that FOSS be used, or at least considered, as an alternative to proprietary software. Such affinity toward FOSS includes economic considerations, but also a strong belief that national interest is served by keeping software code transparent and investment money local.

This article has given much attention to government use and promotion of FOSS at the national level. The relatively small number of countries in South America makes it difficult to draw conclusions without studying more local levels of government.

Beyond the Argentinian provinces that were studied here, other provincial or municipal FOSS implementations could be queried to better discern FOSS GIS uptake throughout the continent. Surveying the private sector, as well as educational and nonprofit institutions, would help to provide a well-rounded assessment. It would be informative to examine the evolution of FOSS GIS use in higher education and what kind of effects (if any) this has wrought on the general software mix in each country. 
This article discussed three case studies of particularly successful efforts to promote FOSS GIS and rally local user groups through education and sharing of technical expertise. The common thread between these case studies is their ability to connect individuals. The FOSSGIS Brasil online magazine connected professionals throughout a large and diverse country. The Geoinquietos Argentina group keeps practitioners constantly connected through modern mobile messaging technologies and regular meetups. The FOSS.4GIS.GOV conferences connect government officials across different ministries and a variety of jurisdictional levels.

Each of these three efforts was driven by highly motivated people who have embraced FOSS and want to see its use expand throughout their local regions. Reasons given for this support include economic benefits (as mentioned by IBAMA's Evaristo), but have also included themes of sovereignty and politics (such as the declarations by Geoinquietos Argentina members that it is in the national interest for software investments to stay local). These ideas of FOSS implementation as manifestations of political and economic independence resonate in South America.

The Argentinian and Brazilian government employees involved in these case studies exhibit some characteristics of Shaw's (2011) 'insurgent experts' who instigated migrations to FOSS after infiltrating the ministries of Lula's Brazil. They exercised the power available to them to implement FOSS GIS in their respective agencies. At the same time, government entities in South America and elsewhere often see employees using a mix of FOSS and proprietary software to satisfy both personal preference and functional needs. Hybrid approaches are likely to remain popular, although the above study of national web map viewers does convey the lesson that when FOSS is mandated, FOSS gets used. 
What can FOSS advocacy groups around the world learn from these case studies? The retiring of the FOSSGIS Brasil magazine and the sometimes-fizzling activity levels of some of the other technical support groups mentioned above (such as Maptime) demonstrate that long-term momentum can be a challenge. This is especially true with FOSS, as much work is done by volunteers whose interests and availability may change as they progress through different jobs and life stages. The decentralized nature of Geoinquietos Argentina seems to have helped impart staying power, with the Telegram messaging system keeping the group agile, inclusive, and in touch. Finally, the presence of supportive partnering institutions can provide a venue for meetings and supply a pool of interested and active individuals.

Face-to-face gatherings take an extraordinary effort to execute, but can boost recruitment and strengthen the core group of organizers both technically and socially. The global FOSS4G conference came to Africa (Dar es Salaam) for the first time in 2018, and Geoinquietos Argentina is preparing a bid to host the conference in Buenos Aires in 2021. Re-evaluating the 'North America, Europe, Rest of the World' three-year FOSS4G conference rotation to include a more flexible mix of countries could help foster a more global focus for OSGeo (although the practice does ensure that North America and Europe do not always dominate the bid process). In the meantime, OSGeo's support for regional and local conferences has helped strengthen new FOSS communities.

The use of government offices by both FOSS4G Argentina and FOSS.4GIS.GOV helped keep fees down and allowed more people to attend, a contrast with the worldwide FOSS4G 2017 conference in Boston that was held at the Seaport Hotel and World Trade Center and cost a hefty $\$ 800$ per person for registration. Nonetheless, nongovernmental funding streams are also helpful: the FOSS.4GIS.GOV 
2018 conference in Brazil was smaller than the 2016 iteration due to fewer funding sources, but the long-term outlook for the continuation and expansion of the conference appears positive if it keeps strong ties with OSGeo. This conference and the other initiatives mentioned above should be of future interest to those who are promoting and developing FOSS as the software increases in accessibility and popularity.

\section{Acknowledgements}

The author would like to thank the members of the FOSS GIS communities in South America who welcomed him to their gatherings and provided feedback on this manuscript. Also deserving of thanks are student Benito Gonzalez for Internet research, and the Office of International Studies and Programs at Central Washington University for financial assistance.

Translations from Spanish and Portuguese are by the author.

\section{References}

Aksulu, A. and Wade, M., 2010. A Comprehensive Review and Synthesis of Open Source Research. Journal of the Association for Information Systems, 11 (11).

Baller, S., Dutta, S., and Lanvin, B., 2016. The Global Information Technology Report 2016. World Economic Forum.

Birkinbine, B., 2016. Free Software as Public Service in Brazil: An Assessment of Activism, Policy, and Technology. International Journal of Communication, 10 (0), 16.

Brovelli, M.A., Mitasova, H., Neteler, M., and Raghavan, V., 2012. Free and open source desktop and Web GIS solutions. Applied Geomatics, 4 (2), 65-66.

Câmara, G. and Fonseca, F., 2007. Information Policies and Open Source Software in Developing Countries. J. Am. Soc. Inf. Sci. Technol., 58 (1), 121-132. 
Câmara, G., Souza, R.C.M., Freitas, U.M., and Garrido, J., 1996. SPRING: Integrating remote sensing and GIS by object-oriented data modelling. Computers \& Graphics, $20(3), 395-403$.

Câmara, G., Vinhas, L., Ferreira, K.R., Queiroz, G.R.D., Souza, R.C.M.D., Monteiro, A.M.V., Carvalho, M.T.D., Casanova, M.A., and Freitas, U.M.D., 2008. TerraLib: An Open Source GIS Library for Large-Scale Environmental and Socio-Economic Applications. In: G.B. Hall and M.G. Leahy, eds. Open Source Approaches in Spatial Data Handling. Berlin, Heidelberg: Springer Berlin Heidelberg, 247-270.

CENATIC, 2010. Report on the International Status of Open Source Software 2010. National Open Source Software Observatory, No. 04. Available from: https://opensource.org/files/Report\%20on\%20the\%20International\%20Status\%20o f\%20Open\%20Source\%20Software\%202010.pdf [Accessed 11 June 2019].

Chan, A., 2004. Coding Free Software, Coding Free States: Free Software Legislation and the Politics of Code in Peru. Anthropological Quarterly, 77 (3), 531-545.

Chan, A., 2007. Retiring the Network Spokesman: The Poly-Vocality of Free Software Networks in Peru. Science \& Technology Studies.

Day to Day, 2004. Brazil Switches from Microsoft to 'Open Source' Software, National Public Radio. Sep 15. Available from: https://www.npr.org/templates/story/story.php?storyId=3919175 [Accessed 14 June 2019].

Dias, T., 2016. Por que o software livre vai perder espaço no governo federal. Nexo Jornal, 3 Nov.

Evangelista, R., 2014. O movimento software livre do Brasil: política, trabalho e hacking. Horizontes Antropológicos, 20 (41), 173-200.

Free Software Foundation, 2018. What is Free Software? [online]. Available from: https://www.gnu.org/philosophy/free-sw.en.html [Accessed 7 Mar 2019].

Ghosh, R.A., 2003. License fees and GDP per capita: The case for open source in developing countries. First Monday, 8 (12).

Gonzalez-Barahona, J.M., Robles, G., Andradas-Izquierdo, R., and Ghosh, R.A., 2008. Geographic origin of libre software developers. Information Economics and Policy, $20(4), 356-363$.

Grazzi, M. and Jung, J., 2019. What Are the Drivers of ICT Diffusion? Evidence from Latin American Firms. Information Technologies \& International Development, 15 $(0), 15$.

Harris, T. and Weiner, D., 1996. GIS and Society: The Social Implications of How People, Space, and Environment Are Represented in GIS. National Center for Geographic Information and Analysis, No. 96-7. 
James, J., 2003. Free software and the digital divide: opportunities and constraints for developing countries. Journal of Information Science, 29 (1), 25-33.

Kamau, J. and Namuye, S., 2012. A Review of Users Adoption of Open Source Software in Africa. Computer and Information Science, 5 (5), p45.

Karume, S.M. and Mbugua, S., 2012. Trends in Adoption of Open Source Software in Africa. Journal of Emerging Trends in Computing and Information Sciences, 3 (11).

Lewis, J., 2010. Government Open Source Policies [online]. Center for Strategic and International Studies. Available from: https://opensource.org/files/100416_Open_Source_Policies.pdf [Accessed 14 June 2019].

Machado, D., 2017. Software Libre en Ecuador: la necesidad de pasar del discurso a la práctica [online]. Decio Machado. Available from:

http://deciomachado.blogspot.com/2017/07/software-libre-en-ecuador-lanecesidad.html [Accessed 14 June 2019].

Maldonado, E., 2010. The Process of Introducing FLOSS in the Public Administration: The Case of Venezuela. Journal of the Association for Information Systems, 11 (11).

Medeiros, A.M.L. de, 2011. Entrevista: Gilberto Câmara. FOSSGIS Brasil, (1), 24-26.

Mendonça, A., 2012. Entrevista: Fernando Quadro. FOSSGIS Brasil, (5), 47-51.

Milano, M.T., 2016. A construção social do mercado colaborativo de software livre durante o Governo Lula: agentes, estratégias e discursos. Universidade Estadual Paulista. Available from: https://repositorio.unesp.br/handle/11449/139468 [Accessed 14 June 2019].

Miranda, M., 2017. Una comunidad geoinquieta. Presented at FOSS4G+State of the Map Argentina 2017, Buenos Aires, Argentina.

Molina Rodriguez, R.F. and Lesage, S., 2013. Spatial Data Infrastructure of the Plurinational State of Bolivia - A free and democratic SDI. Free and Open Source Software for Geospatial (FOSS4G) Conference Proceedings, 13.

Mota, G.L.A., Nunes e Silva Brito, J.L., Ribeiro, J.A., Filho, O.B., Silveira, M.T., de Aguiar, R.A., da Silva Badolato, I., da Costa, S.L., and Reolon, P.F., 2012. The EFoto Project and the Research to Implement a GNU/GPL Open source Educational Digital Photogrammetric Workstation. In: E. Bocher and M. Neteler, eds.

Geospatial Free and Open Source Software in the 21st Century: Proceedings of the first Open Source Geospatial Research Symposium, OGRS 2009. Berlin, Heidelberg: Springer Berlin Heidelberg, 89-106. 
Nanni, A., 2016. QGISBrasil. Presented at FOSS.4GIS.GOV 2016, Brasília, Brazil. Available from: https://www.youtube.com/watch?v=iSe5JFCw_Kc [Accessed 14 June 2019].

Oram, A., 2011. Promoting Open Source Software in Government: The Challenges of Motivation and Follow-Through. Journal of Information Technology \& Politics, 8 (3), 240-252.

OSGeo, 2017. OSGeo AGM 2017. Presented at the OSGeo Annual General Meeting 2017, Boston, Massachusetts, USA. Available from:

https://www.slideshare.net/jgarnett/osgeo-agm-2017 [Accessed 6 September 2019].

Pavlovskaya, M. and St. Martin, K., 2007. Feminism and Geographic Information Systems: From a Missing Object to a Mapping Subject. Geography Compass, 1 (3), 583-606.

Puentes Vargas, J.P., 2015. Recommendations for the adoption of libre software in the public sector in South America. Tilburg University Law School, Tilburg, Netherlands. Available from: https://www.slideshare.net/JuanPabloPV/recommendations-for-the-adoption-oflibre-software-in-the-public-sector-in-south-america [Accessed 14 June 2019].

Quadro, F., 2016. FOSS4G: Por que os argentinos conseguem, e nós não? Blog do Fernando Quadro. Available from:

http://www.fernandoquadro.com.br/html/2016/04/05/foss4g-por-que-os-argentinosconseguem-e-nos-nao/ [Accessed 5 December 2018].

Revista de la Universidad 2018. 'Geochicas', con Miriam González y Céline Jacquin [online]. Available from: https://www.youtube.com/watch?v=UIoYLUx55TE [Accessed 14 June 2019].

SERPRO, 2010. Governo federal economiza $\mathrm{R} \$ 380 \mathrm{mi}$ ao adotar softwares livres [online]. Available from: http://www.serpro.gov.br/menu/noticias/noticiasantigas/governo-federal-economiza-r-380-mi-ao-adotar-softwares-livres [Accessed 27 May 2019].

Shaikh, M. and Cornford, T., 2012. Strategic drivers of open source software adoption in the public sector: Challenges and opportunities. ECIS 2012 Proceedings.

Shaw, A., 2011. Insurgent Expertise: The Politics of Free/Livre and Open Source Software in Brazil. Journal of Information Technology \& Politics, 8 (3), 253-272.

Sheppard, E., 1995. Sleeping with the enemy, or keeping the conversation going? Environment and Planning A, 27 (7), 1026-1028.

Stallman, R., 2016. Why Open Source misses the point of Free Software [online]. Available from: https://www.gnu.org/philosophy/open-source-misses-the-point.html [Accessed 7 Mar 2019]. 
Steiniger, S. and Hunter, A.J., 2013. The 2012 free and open source GIS software mapA guide to facilitate research, development, and adoption. Computers, Environment and Urban Systems, 39, 136-150.

Sui, D., 2014. Opportunities and Impediments for Open GIS. Transactions in GIS, 18 (1), 1-24.

UNESCO, 2013. Software libre y de código abierto para el desarrollo [online]. UNESCO. Available from: https://es.unesco.org/news/software-libre-yc\%C3\%B3digo-abierto-desarrollo [Accessed 7 Mar 2019].

United Nations, 2018. The World's Cities in 2018: Data booklet. Available from: https://www.un.org/en/events/citiesday/assets/pdf/the_worlds_cities_in_2018_data_ booklet.pdf [Accessed 27 May 2019]

Yapa, L., 1991. Is GIS appropriate technology? International Journal of Geographical Information Systems, 5 (1), 41-58.

Zanotti, A., 2012. Comunidades de Software Libre en Argentina: Algunas Exploraciones y Vectores de Análisis. In: B. Tejerina and I. Perugorría, eds. Global Movements, National Grievances: Mobilizing for 'Real Democracy' and Social Justice. Universidad del País Vasco, 602-620.

Zanotti, A., 2014. Comunidades de software libre en Argentina: motivaciones, participación, militancia. Perspectivas de la Comunicación - ISSN 0718-4867, 7 (2), $55-74$. 